\title{
Reaction of some rapeseed (Brassica napus L.) genotypes to different drought stress levels during germination and seedling growth stages ${ }^{\text {th }}$
}

\author{
Souhail Channaoui ${ }^{1,2}$, Imane Saghouri El Idrissi ${ }^{3}$, Hamid Mazouz ${ }^{2}$ and Abdelghani Nabloussi ${ }^{1, *}$ \\ ${ }^{1}$ Research Unit of Plant Breeding and Plant Genetic Resources Conservation, National Institute of Agricultural Research, \\ Regional Agricultural Research Center of Meknes, Meknes, Morocco \\ ${ }^{2}$ Laboratory of Plant Biotechnology and Molecular Biology, Department of Biology, Faculty of Sciences, University of Moulay Ismail, \\ Meknes, Morocco \\ ${ }^{3}$ Laboratory of Biodiversity and Natural Resources, Department of Biology, Faculty of Sciences, University of Ibn Tofail, Kenitra, \\ Morocco
}

Received 29 June 2018 - Accepted 6 April 2019

\begin{abstract}
Drought is a major abiotic stress that affects seed germination and plant growth in arid and semi-arid regions. Rapeseed is an oilseed crop adapted to Mediterranean area; however, it is reported that it is sensitive to water stress occurring during seed germination. In this study, we investigated how seed germination and early seedling growth of six rapeseed genotypes were influenced by different water stress levels. In addition to the control (absence of drought stress), three drought levels were simulated using three osmotic potentials of polyethylene glycol (PEG-6000), $-9,-10$ and -11 bars. A completely randomized design with three replications was used for this experiment. Germination percentage (GP), shoot length (SL), root length (RL), shoot elongation rate (SER) and root elongation rate (RER) were determined to evaluate the genotypes response to PEG-induced drought stress. Results showed drought stress, genotype and interaction stress $\times$ genotype had a significant effect on the studied parameters. GP decreased with the increase in stress level. The genotype 'Nap9' was the most interesting, having the highest GP values, namely $63.33,62.67$ and $28 \%$ under the stress levels $-9,-10$ and -11 bars, respectively. The genotype 'H2M-5', which ranked second with respect to this parameter, was statistically comparable to 'Nap9'. Also, SL, RL, SER and RER decreased with the increase in drought stress level. However, the studied genotypes reacted differently to various water stress levels. Once again, the genotype 'H2M-5' exhibited the highest average RL and RER under all drought levels. Particularly, for severe drought conditions ( -11 bars), 'H2M-5' had an average RL of $1.54 \mathrm{~cm}$ and RER of $0.36 \mathrm{~cm} / \mathrm{d}$. Field evaluation under controlled conditions is needed to confirm findings of the present experiment. The mutant ' $\mathrm{H} 2 \mathrm{M}-5$ ' could be a valuable and promising germplasm for developing a performant and adapted variety to be designed for harsh environments particularly characterized by early drought coinciding with germination and seedling growth stages.
\end{abstract}

Keywords: drought / osmotic potential / rapeseed / mutant / seed germination / seedling growth

\begin{abstract}
Résumé - Réaction de certains génotypes de colza (Brassica napus L.) à différents niveaux de stress hydrique au cours des stades de germination et de croissance précoce de jeunes plantules. La sécheresse est un stress abiotique majeur qui affecte la germination des graines et la croissance des plantes dans les régions arides et semi-arides. Le colza est une culture oléagineuse adaptée à la région méditerranéenne, mais qui reste sensible au stress hydrique survenant pendant la germination des graines. L'effet de différents niveaux de stress hydrique sur la germination des graines et la croissance précoce des jeunes plantules de six génotypes de colza a été étudié. Outre le contrôle (absence de stress), trois niveaux de sécheresse ont été simulés à l'aide de trois potentiels osmotiques de polyéthylène glycol (PEG-6000), -9, 10 et -11 bars. Un dispositif en blocs aléatoires complets, avec trois répétitions, a été utilisé pour cette étude.
\end{abstract}

\footnotetext{
Contribution to the Topical Issue "Rapeseed / Colza"

*Correspondence: abdelghani.nabloussi@gmail.com
} 
Le pourcentage de germination (GP), la longueur des pousses (SL), la longueur des racines (RL), le taux d'élongation des pousses (SER) et le taux d'élongation des racines (RER) ont été déterminés pour évaluer la réponse des génotypes au stress hydrique induit par le PEG. Les résultats ont montré que le stress hydrique, le génotype et l'interaction stress $\times$ génotype ont un effet significatif sur les paramètres étudiés. GP diminue de plus en plus que le niveau du stress augmente. Le génotype 'Nap9' est le plus intéressant, ayant les valeurs de GP les plus élevées, à savoir $63,33,62,67$ et $28 \%$ sous les niveaux de stress de $-9,-10$ et -11 bars, respectivement. De même, le génotype 'H2M-5' (mutant), qui s'est classé deuxième en ce qui concerne ce paramètre, était statistiquement comparable à 'Nap9'. Les paramètres SL, RL, SER et RER ont diminué également avec l'accroissement du niveau de stress. Cependant, les génotypes étudiés ont réagi différemment à ces niveaux de stress hydrique. Encore une fois, le génotype 'H2M-5' présente les taux moyens de RL et de RER les plus élevés, quel que soit le niveau de sécheresse. En particulier, dans des conditions de sécheresse sévère ( -11 bars), ce génotype se distingue par un RL moyen de 1,54 cm et un RER de $0,36 \mathrm{~cm} / \mathrm{j}$. Une évaluation sur le terrain dans des conditions contrôlées est nécessaire pour confirmer les résultats de la présente étude. Le mutant ' $\mathrm{H} 2 \mathrm{M}-5$ ' pourrait être un germoplasme précieux et prometteur pour le développement d'une variété performante et adaptée, conçue pour les environnements difficiles caractérisés, notamment, par une sécheresse précoce coïncidant avec les stades de germination et de croissance de jeunes plantules.

Mots clés : sécheresse / potentiel osmotique / colza / mutant / germination des graines / croissance des plantules

\section{Introduction}

Abiotic stresses, such as drought, salinity and extreme temperatures are serious threats to agriculture and result in the deterioration of the environment (Narusaka et al., 2003; Pena and Hughes, 2007) and in crop loss, reducing average yields for most major crop plants by more than $50 \%$ (Boyer, 1982; Buchanan et al., 2000; Bartels and Sunkar 2005; Mittler, 2006; Wu et al., 2011). One of the most important abiotic factors limiting seed germination and early seedling growth is water stress (Ashraf et al., 1992; Almansouri et al., 2001; Ansari et al., 2013). Particularly, seed germination is first critical in seedling establishment, determining successful crop production (Almansouri et al., 2001) and, at the same time, the most sensitive stage in the life cycle of plants (Ashraf and Mehmood, 1990). In fact, crop establishment depends on an interaction between seedbed environment and seed quality (Brown et al., 1989; Khajeh-Hosseini et al., 2003). In other words, any unfavorable seedbed environment conditions, like drought stress, may have to compromise this crop establishment (Albuquerque and Carvalho, 2003) and then the seed yield (Mwale et al., 2003; Okcu et al., 2005).

Rapeseed (Brassica napus L.), a very important oilseed crop, source of vegetable oil and protein-rich meal, is characterized by a substantially increased world production over the last 35 years, which currently reached six times the production recorded in 1980 (Wanasundara et al., 2016). In 2016, the overall production was around 69 million tons (FAOSTAT, 2018). In Morocco as well as in other countries of Mediterranean area, rapeseed shows a good adaptation and has a great potential, as a promising oilseed crop, to play a role in improving the production vegetable oils in such countries. Planted in late autumn and harvested in early summer, rapeseed is often exposed to different drought stress periods, from germination to seed filling, that affect plant growth and development in arid and semi-arid areas of this country. Although drought can occur at any time during the growing season, two main periods of drought are more likely: the early one that coincides with seed germination and seedling emergence and the terminal drought that affects seeds set and filling (Watts and El Mourid, 1988). Therefore, selection and development of varieties with good drought resistance or tolerance, during germination and early seedling growth stages, will contribute to more stable rapeseed production. Previous studies showed that there is a genetic variability in Brassica species response to water stress during germination and early seedling growth stages (Mohammadi and Amiri, 2010; Toosi et al., 2014; Channaoui et al., 2017). However, controlled and uniformly repeated simulation of drought in the field cannot be easily achieved (Shaheen and Hood-Nowotny, 2005), which make field trials difficult for drought genotypes screening. One technique for studying the effect of drought stress on germination is to simulate stress conditions using artificial solutions to provide variable osmotic potentials (Larson and Shubert 1969; Falusi et al., 1983). In many plants, polyethylene glycol (PEG-6000) is commonly used to simulate osmotic stress effects in petri dish (in vitro). Since PEG-6000 is not absorbed by the plants, its concentration remains fixed in the whole duration of the stress and that is why it is known as the best treatment for osmotic stress compared to other osmolytes such as mannitol, sugar, and salt (Kramer and Boyer, 1995; Dami and Haghes, 1997).

In a previous study, the response of some Moroccan rapeseed varieties to PEG-induced drought stress at germination and early seedling growth was evaluated using various PEG concentrations $(-3,-5,-7,-9,-11$ and -13 bars) (Channaoui et al., 2017). Recently, through rapeseed mutagenesis breeding, promising mutants were developed and there is a need to characterize and evaluate them for their tolerance/sensitivity to drought stress in different growth stages. Based on findings of Channaoui et al. (2017), only three PEG solutions with osmotic potentials of $-9,-10$ and -11 bars were used to investigate the reaction of five promising advanced $\mathrm{M}_{3}$ rapeseed mutants and one introduced Australian variety to drought during germination. In addition to the parameters measured in Channaoui et al. (2017), shoot and root elongation rates were considered to better evaluate the reaction of genotypes at different levels of drought stress. Therefore, the objective of this study was to assess and 
compare the response of some promising rapeseed mutants, along with an introduced Australian cultivar, to drought stress at germination and early seedling growth under controlled conditions, and to identify the most tolerant genotype(s) to such conditions.

\section{Materials and methods}

\subsection{Plant material and drought stress treatment}

This study was carried out at the National Institute for Agricultural Research (INRA) of Morocco (Regional Center of Meknes). The used plant material consisted of six rapeseed (Brassica napus L.) genotypes: five promising advanced $\mathrm{M}_{3}$ mutants of rapeseed 'H2M-1', 'H2M-2', 'H2M-3', 'H2M-4' and 'H2M-5' and one Australian variety 'Nap9'. The seeds experimented in the present study were randomly taken from seed lots obtained through seed increasing in the same field and under the same conditions for all genotypes. Drought stress was induced by polyethylene glycol (PEG-6000) solutions. Application of three levels of drought stress, with osmotic potentials of $-9,-10$ and -11 bars, was done as described by Michel \& Kaufmann (1973). Distilled water was used as control. As stated in the introduction section, the choice of osmotic potentials used in this study was based on findings of our previous research on some Moroccan rapeseed varieties (Channaoui et al., 2017).

\subsection{Germination test and parameters measured}

For each treatment, three replications of 50 seeds of each genotype were used to evaluate the effect of drought stress during germination and early seedling growth on the performance of the studied genotypes. Seeds were sterilized in a solution of 5\% sodium hypochlorite for $1 \mathrm{~min}$ and then carefully rinsed with distilled water to remove any traces of sterilizing agent, and were allowed to germinate in a Petri dish double lined with filter paper moistened with $15 \mathrm{ml}$ of the respective test solutions at $25 \pm 1{ }^{\circ} \mathrm{C}$, in the dark, in an incubator for 8 days. Every $24 \mathrm{~h}, 2 \mathrm{ml}$ of each solution was added to Petri dish. Germination percentage (GP, \%) was counted after 2, 4, 6 and 8 days following seeds placement in Petri dishes for germination, using radicle extrusion $(\geq 3 \mathrm{~mm}$ long) as germination indicator. Shoot and root length (SL and $\mathrm{RL}, \mathrm{cm}$ ) were measured on the eighth day after germination (end of experiment). Shoot length was measured from the cotyledons to the collar, while the root length was measured from the collar to the root tip. Shoot elongation rate (SER, $\mathrm{cm} / \mathrm{d})$ was determined by $\mathrm{SER}=(\mathrm{SLE}-\mathrm{SLS}) /(\mathrm{TE}-\mathrm{TS})$. Where SLE $(\mathrm{cm})$ and SLS $(\mathrm{cm})$ are the shoot length at the end and start of a measurement period, respectively, and TE-TS

the time duration between SLE and SLS measurements. Root elongation rate (RER, cm/d) was computed as $R E R=(R L E-R L S) /(T E-T S)$ or the difference in root length (cm) at the end (RLE) and start (RLS) of a measurement period, divided by the difference in time (d) from start (TS) to end (TE) of the measurement period. Shoot and root elongation rates were measured on four successive two days-periods, until the end of the experiment period (eight days): P1 (0-2nd day), P2 (2nd-4th days), P3 (4th-6th days) and P4 (6th-8th days).

\subsection{Experimental design}

The experimental design was a completely randomized double factorial, with 3 replications and 50 seeds per replication. The first factor was the genotypes (Nap9, H2M-1, H2M2, H2M-3, H2M-4 and H2M-5) and the second was the stress solution of PEG-6000 ( $0,-9,-10$ and -11 bars $)$. Data for germination and seedling growth were subjected to an analysis of variance (ANOVA) to determine statistically significant differences among genotypes, drought levels and their interaction levels, using software package SPSS for Windows (Version 22). Duncan's new multiple range test (DMRT) was applied to compare treatment means.

\section{Results}

\subsection{Effects of osmotic stress at germination}

According to results of analysis of variance, seed germination percentage (GP) was significantly affected by osmotic potential and genotype. However, interaction between genotype and stress level had no significant effect on this parameter (Tab. 1). Figure 1 shows that, for all genotypes, lowering of water potential resulted in a significant reduction of germination capacity. The final GP of the control (absence of stress) reached $100 \%$ for all genotypes (Fig. 1). Under stress conditions, the minimum GP values $(28,1.33,13.33,0.67,10$ and $24.67 \%$ ) were recorded for the severe stress ( -11 bars), whilst the maximum ones $(63.33,34.67,46.67,46,39.33$ and $45.33 \%$ ) were registered for the moderate stress ( -9 bars). The genotype 'Nap9' exhibited the highest GP (63.33, 62.67 and $28 \%$ ) under the three stress levels $-9,-10$ and -11 bars, respectively, while the genotype ' $\mathrm{H} 2 \mathrm{M}-1$ ' had the minimum one $(34.67,15.33$ and $1.33 \%)$ for these respective stress levels (Fig. 1). In absence of stress (control treatment), and for the six studied genotypes, the maximum GP was reached already from the second day of strict imbibition, after which GP was almost invariable (Fig. 2). Under severe stress ( -11 bars), GP did not begin until the 4th day of imbibition, in case of genotypes 'Nap9' and 'H2M-5', and the 6th day for genotypes 'H2M-2' and 'H2M-4'. Regarding the other two genotypes, 'H2M-1' and 'H2M-3', no germination was recorded (Fig. 2). At this level of water potential, 'Nap9' and 'H2M-5' showed the highest GP values ever registered, namely 28 and $24.67 \%$, respectively, while 'H2M-1' and 'H2M-3' had the most drastic reduction in GP, with values of 1.33 and $0.67 \%$, respectively (Figs. 1, 2). This indicated that, in terms of germination, 'Nap9' and 'H2M-5' were the best performing genotypes under extreme drought stress conditions, and 'H2M-1' and 'H2M-3' were the most sensitive. The other genotypes showed an intermediate behavior.

\subsection{Effects of osmotic stress at seedling stage}

Analysis of variance showed that there were significant differences among genotypes and between drought stress levels for shoot length (SL), root length (RL), shoot elongation rate (SER) and root elongation rate (RER) (Tab. 1). Also, the effect of drought stress $\times$ genotype interaction on SL, RL and RER was significant, indicating that genotypes reacted differently to the drought levels for these parameters. 
Table 1. Analysis of variance (mean squares) for seed germination and seedling related traits of six rapeseed genotypes evaluated under drought stress conditions.

\begin{tabular}{|c|c|c|c|c|c|c|}
\hline Source of variation & Degree of freedom & Germination percentage & Shoot length & Root length & Shoot elongation rate & Root elongation rate \\
\hline Drought (D) & 3 & $25295.19 * * *$ & $166.67 * * *$ & $118.44 * * *$ & $3.75 * * *$ & $2.82 * * *$ \\
\hline
\end{tabular}

*** Significant at $0.05,0.01$ and 0.001 probability level, respectively.

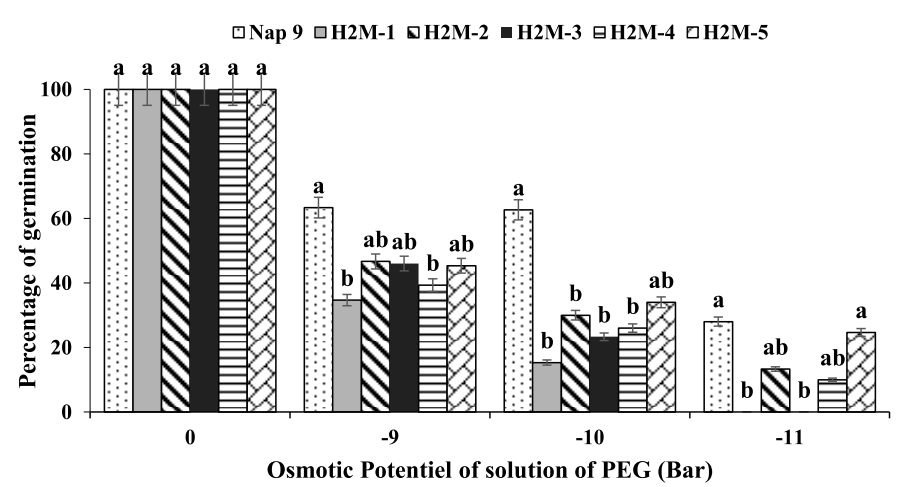

Fig. 1. Effect of PEG induced drought stress on germination percentage of seeds from six rapeseed genotypes. (Values with different alphabetical superscripts are significantly different $(p=0.05)$ according to DMRT).

In absence of stress, 'H2M-4' had the highest average SL $(7.59 \mathrm{~cm})$ followed by 'H2M-2' and 'H2M-5' (6.47 and $6.55 \mathrm{~cm}$, respectively), while ' $\mathrm{H} 2 \mathrm{M}-3$ ' exhibited the lowest one $(5.44 \mathrm{~cm})$ (Fig. 3). At the osmotic potential of -9 bars, a drastic reduction in SL was observed (Fig. 3). Overall, the genotypes 'H2M-5' showed the highest average SL $(0.5 \mathrm{~cm})$, whilst the genotype 'H2M-1' showed the lowest one $(0.21 \mathrm{~cm})$. The other genotypes, 'Nap9', 'H2M-2', 'H2M-3' and 'H2M-4' had intermediate SL value (Fig. 3). Besides, the genotypes 'H2M-5' and 'H2M-4' were the only ones able to develop shoots at PEG-induced osmotic potentials of -10 and -11 bars (Fig. 3).

Shoot elongation rate (SER) of the studied genotypes, as affected by different levels of drought stress, is presented in Table 2 and Figure 4. SER varied through the four periods and between the six genotypes whatever the stress levels. In absence of PEG stress, the highest SER during P1 and P2 was recorded in the genotype 'H2M-4' $(0.65$ and $0.97 \mathrm{~cm} / \mathrm{d}$, respectively), while the lowest ones were detected for 'Nap9' (0.18 and $0.65 \mathrm{~cm} / \mathrm{d}$, respectively) (Fig. 4). During P3, the genotype 'H2M-5' had the highest SER $(1.24 \mathrm{~cm} / \mathrm{d})$, whilst 'H2M-4' had the lowest one $(0.84 \mathrm{~cm} / \mathrm{d})$ (Fig. 4). Also during $\mathrm{P} 4$, the genotype 'H2M-4' exhibited quite high SER $(1.34 \mathrm{~cm} /$ d), while 'H2M-3' and 'H2M-2' had too much lower SER, with an average of 0.84 and $0.86 \mathrm{~cm} / \mathrm{d}$, respectively (Fig. 4). Under water stress conditions, SER decreased drastically for all six genotypes. In fact, at the osmotic potential of -9 bars, the highest SER was just $0.14 \mathrm{~cm} / \mathrm{d}$, during the second period $\mathrm{P} 2$, recorded in the genotype ' $\mathrm{H} 2 \mathrm{M}-3$ ', followed by ' $\mathrm{H} 2 \mathrm{M}-4$ ' and 'H2M-5' having an average SER of $0.05 \mathrm{~cm} / \mathrm{d}$. On the other hand, the other genotypes had a shoot elongation rate of zero at this period (Fig. 4). During the following periods (P3 and $\mathrm{P} 4)$, 'H2M-5' and 'H2M-4' showed the highest average $(0.12 \mathrm{~cm} / \mathrm{d})$ (Fig. 4). Under -10 bars, 'H2M-5' was the only one which grew shoot at a rate of $0.12 \mathrm{~cm} / \mathrm{d}$ during P3 (Fig. 4). During $\mathrm{P} 4$, the genotypes 'H2M-4' and 'H2M-5' had an average SER of 0.11 and $0.04 \mathrm{~cm} / \mathrm{d}$, respectively (Fig. 4). Finally, for severe drought ( -11 bars), the mutants ${ }^{~} \mathrm{H} 2 \mathrm{M}-5$ and 'H2M-4' were the only ones able to grow shoots at a rate of 0.07 and $0.08 \mathrm{~cm} / \mathrm{d}$, respectively, during P4 (Fig. 4). It is also noteworthy that, in absence of stress, the genotypes 'Nap9', 'H2M-1' and 'H2M-4' exhibited peak of their SER during P4, while 'H2M-2', 'H2M-3' and 'H2M-5' genotypes exhibited peak during P3 (Fig. 4). Under stress levels, the genotypes 'Nap9', 'H2M-1', 'H2M-2' and 'H2M-5' showed a maximum rate during $\mathrm{P} 3$, whilst 'H2M-3' and 'H2M-4' showed a peak during P2 and P4, respectively (Fig. 4). Overall, the mutant 'H2M-5' had the highest average SER, $0.05 \mathrm{~cm} / \mathrm{d}$, all drought levels (osmotic potentials) and periods combined (Tab. 2).

Likewise, PEG-induced stress led to a substantial decrease in RL of all genotypes excepted ' $\mathrm{H} 2 \mathrm{M}-5$ ', compared to the non-stressed control. The highest average RL was observed in absence of drought (control), and under stress conditions, RL decreased for all genotypes (Fig. 5). However, by increasing drought level, different reaction among the investigated genotypes was observed. For all drought stress levels, the mutant 'H2M-5' developed the longest root, with an average of $4.05,2.14$ and $1.54 \mathrm{~cm}$ for $-9,-10$ and -11 bars, respectively, followed by the variety 'Nap9', with an average of $2.41,1.78$ and $0.61 \mathrm{~cm}$, respectively. The mutants ' $\mathrm{H} 2 \mathrm{M}-1$ ' and ' $\mathrm{H} 2 \mathrm{M}-3$ ' showed the minimum mean values of RL $(0.64$ and $0.82 \mathrm{~cm}$, respectively), under -10 bars, and failed to germinate under -11 bars. At the osmotic potential of -9 bars, ' $\mathrm{H} 2 \mathrm{M}-1$ ' and 'H2M-3' had the lowest average RL, 1.21 and $1.30 \mathrm{~cm}$, respectively (Fig. 5).

Effect of PEG induced drought stress on root elongation rate (RER) of the studied rapeseed genotypes over time is shown in Figure 6 . The obtained results revealed that RER varied through periods and among genotypes both in absence and presence of drought stress. In absence of stress, the genotype 'H2M-5' had the highest RER during P2, P3 and P4 $(0.9,1.3$ and $1.41 \mathrm{~cm} / \mathrm{d}$, respectively), while 'H2M-3' had the highest RER during P1 $(0.57 \mathrm{~cm} / \mathrm{d})$. Under water stress, the root elongation rate of the six genotypes decreased significantly. At the osmotic potential of -9 bars, and during the period P1, the genotypes ' $\mathrm{H} 2 \mathrm{M}-3$ ' ' $\mathrm{H} 2 \mathrm{M}-5$ ' were the only ones able to grow root at a rate of $0.15 \mathrm{~cm} /$ d (Fig. 6). Furthermore, the genotype ' $\mathrm{H} 2 \mathrm{M}-5$ ' had the highest RER during P2, P3 and P4, being $0.47,0.55$ and $0.86 \mathrm{~cm} / \mathrm{d}$, respectively (Fig. 6). Under -10 bars, no genotype was able to develop shoots at P1, but during the following periods (P2 and $\mathrm{P} 3)$, 'H2M-5' showed the highest average, being 0.25 and 

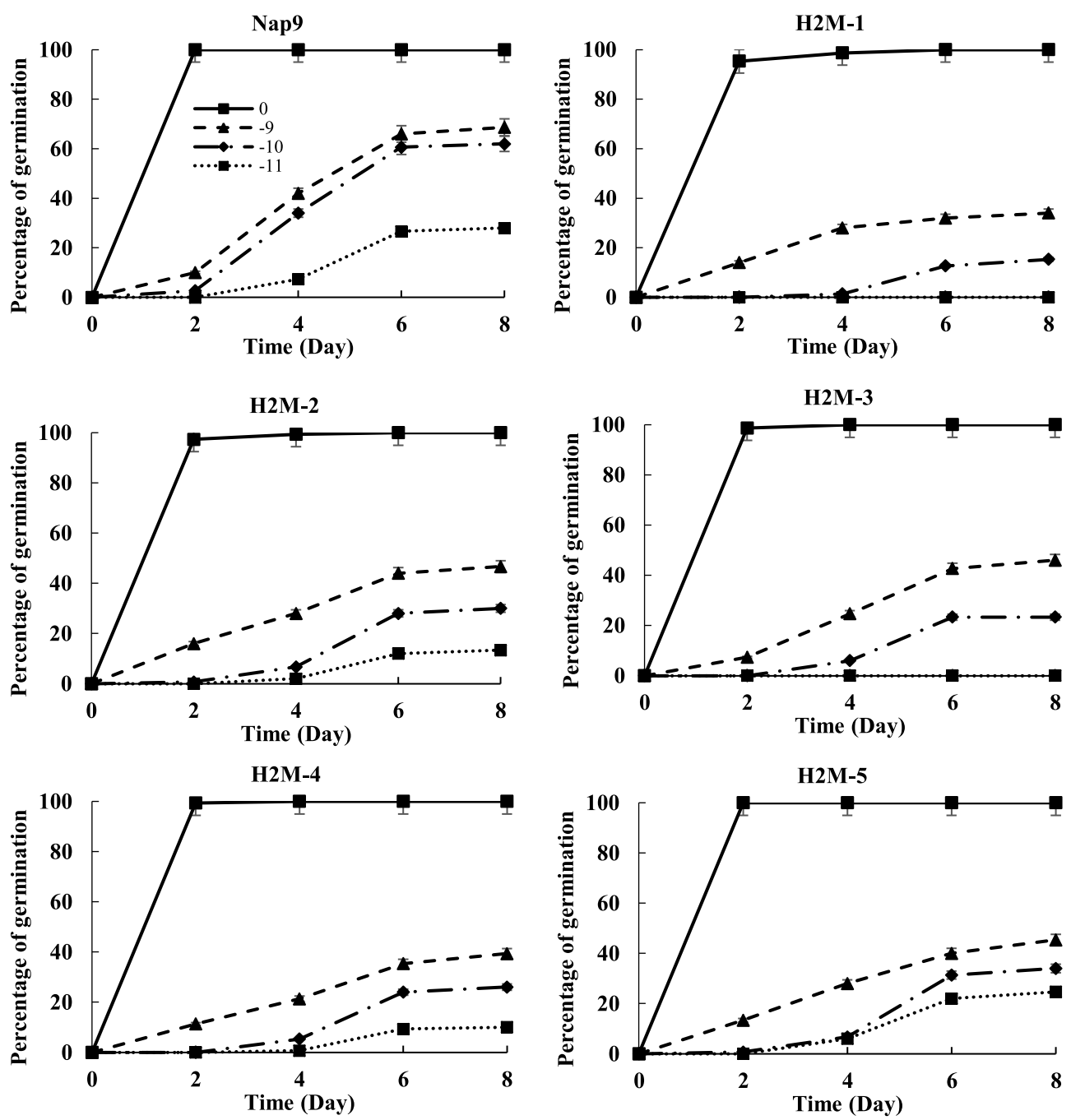

Fig. 2. Effect of PEG induced drought stress (bars) on kinetic of seeds germination in six rapeseed genotypes.

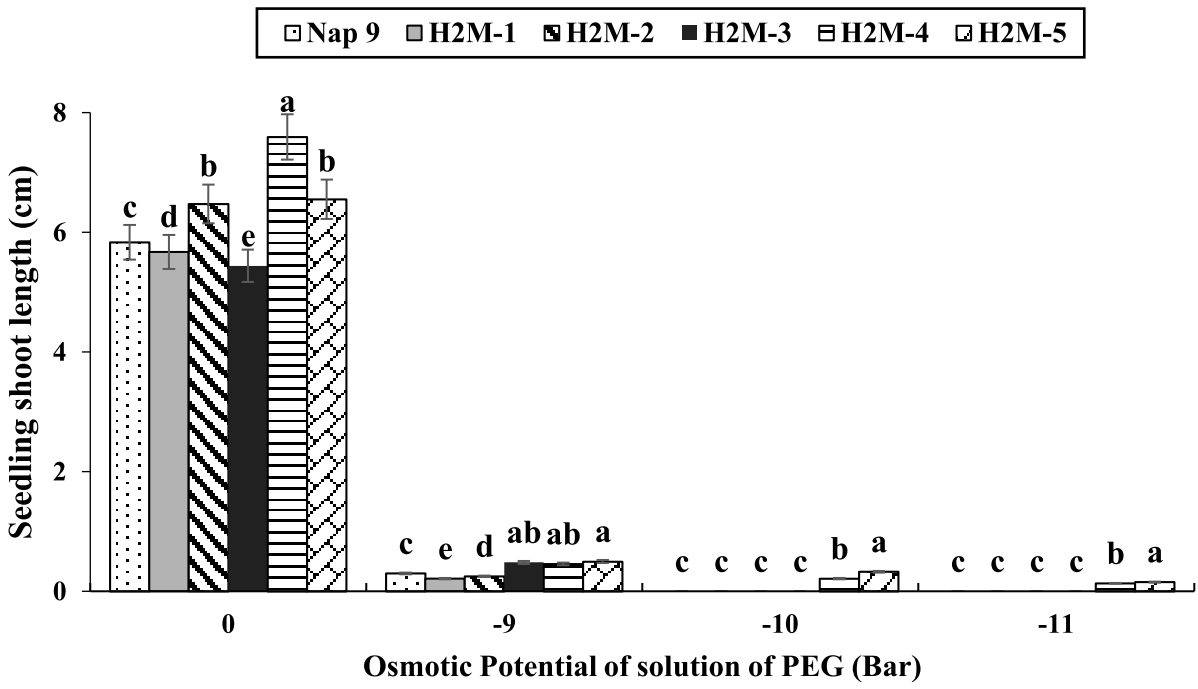

Fig. 3. Effect of PEG induced drought stress on seedling shoot length of six rapeseed genotypes. (Values with different alphabetical superscripts are significantly different ( $p=0.05)$ according to DMRT). 
Table 2. Average of shoot and root elongation rates (SER, RER) of six rapeseed genotypes evaluated under drought stress conditions.

\begin{tabular}{|c|c|c|c|c|c|c|c|c|c|c|c|c|}
\hline $\begin{array}{l}\text { OP } \\
\text { (bar) }\end{array}$ & \multicolumn{2}{|c|}{ Nap 9} & \multicolumn{2}{|c|}{ H2M-1 } & \multicolumn{2}{|c|}{ H2M-2 } & \multicolumn{2}{|c|}{ H2M-3 } & \multicolumn{2}{|c|}{ H2M-4 } & \multicolumn{2}{|c|}{ H2M-5 } \\
\hline 0 & 0.73 & 0.79 & 0.71 & 0.75 & 0.81 & 0.78 & 0.68 & 0.85 & 0.95 & 0.65 & 0.82 & 0.94 \\
\hline-10 & 0 & 0.22 & 0 & 0.08 & 0 & 0.12 & 0 & 0.1 & 0.03 & 0.22 & 0.06 & 0.27 \\
\hline-11 & 0 & 0.08 & 0 & 0 & 0 & 0.07 & 0 & 0 & 0.02 & 0.08 & 0.02 & 0.19 \\
\hline
\end{tabular}
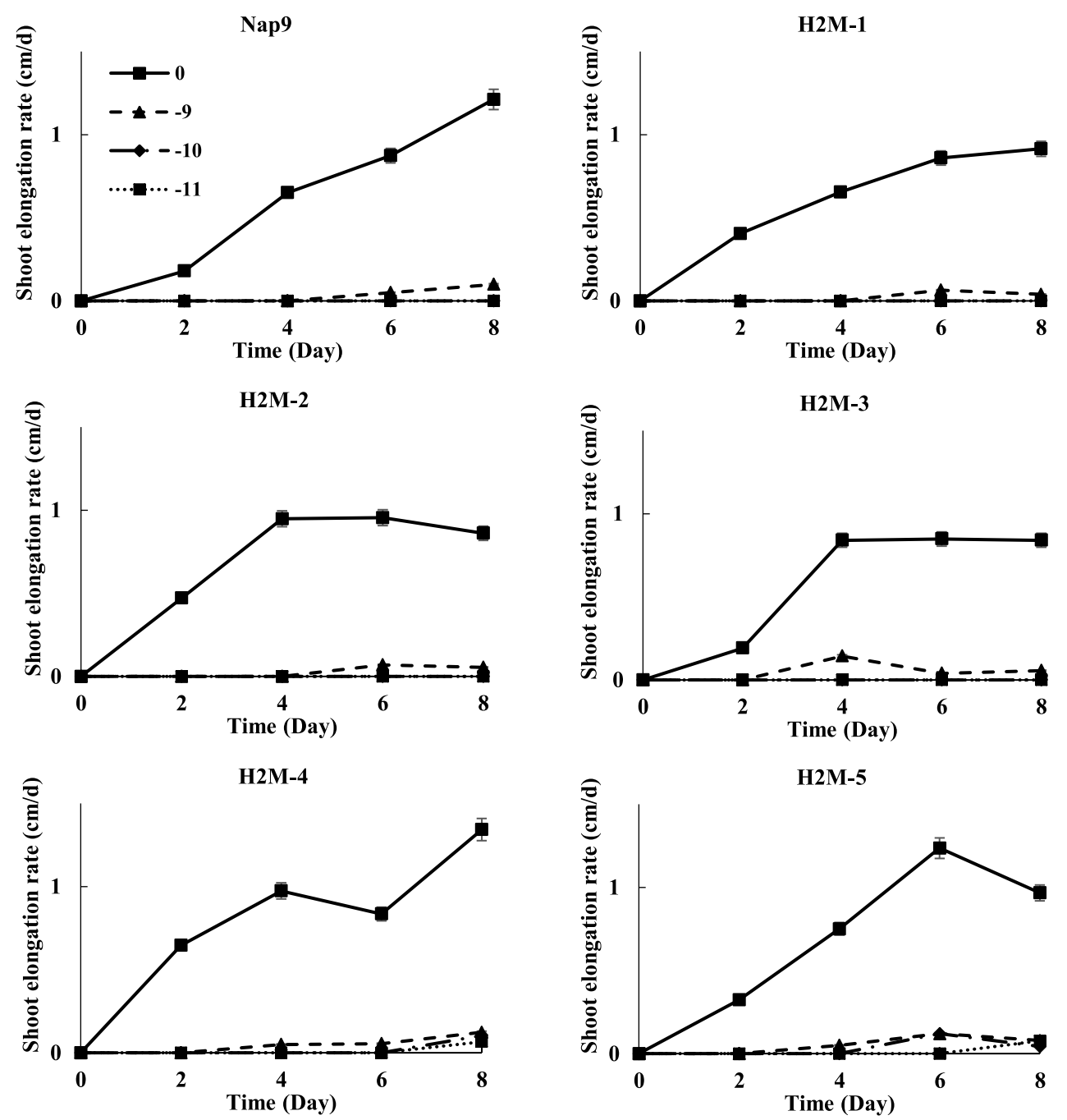

Fig. 4. Effect of PEG induced drought stress on shoot elongation rate over time of seeds from six rapeseed genotypes.

$0.46 \mathrm{~cm} / \mathrm{d}$, respectively, while 'H2M-4' had the highest average $(0.43 \mathrm{~cm} / \mathrm{d})$ during P4 (Fig. 6).

At the osmotic potential of -11 bars, during $\mathrm{P} 2$, the genotypes 'Nap9' and 'H2M-5' were the only ones able to grow roots at a rate of 0.17 and $0.15 \mathrm{~cm} / \mathrm{d}$, respectively (Fig. 6). During P3 and P4, the highest RER was recorded in the mutant ' $\mathrm{H} 2 \mathrm{M}-5$ ' ( 0.24 and $0.38 \mathrm{~cm} / \mathrm{d}$, respectively). One could observe that, in absence of stress, 'Nap9', 'H2M-1', 'H2M-3' and 'H2M-4' genotypes exhibited peak of their RER during P3, while 'H2M2' and 'H2M-5' genotypes exhibited peak during P4 (Fig. 6). Under stress conditions, the genotypes 'Nap9', 'H2M-4' and
'H2M-5' showed a maximum rate during $\mathrm{P} 4$, while ' $\mathrm{H} 2 \mathrm{M}-1$ ', 'H2M-2' and 'H2M-3 showed a peak during P3 (Fig. 6). Overall, the highest average RER, all drought levels and periods pooled, was $0.32 \mathrm{~cm} / \mathrm{d}$ observed in the mutant 'H2M-5' (Tab. 2).

\section{Discussion}

In the present study, regardless of the genotypes, increasing drought at germination stage, by lowering the water potential, reduced the capacity for germination. This is in agreement with 


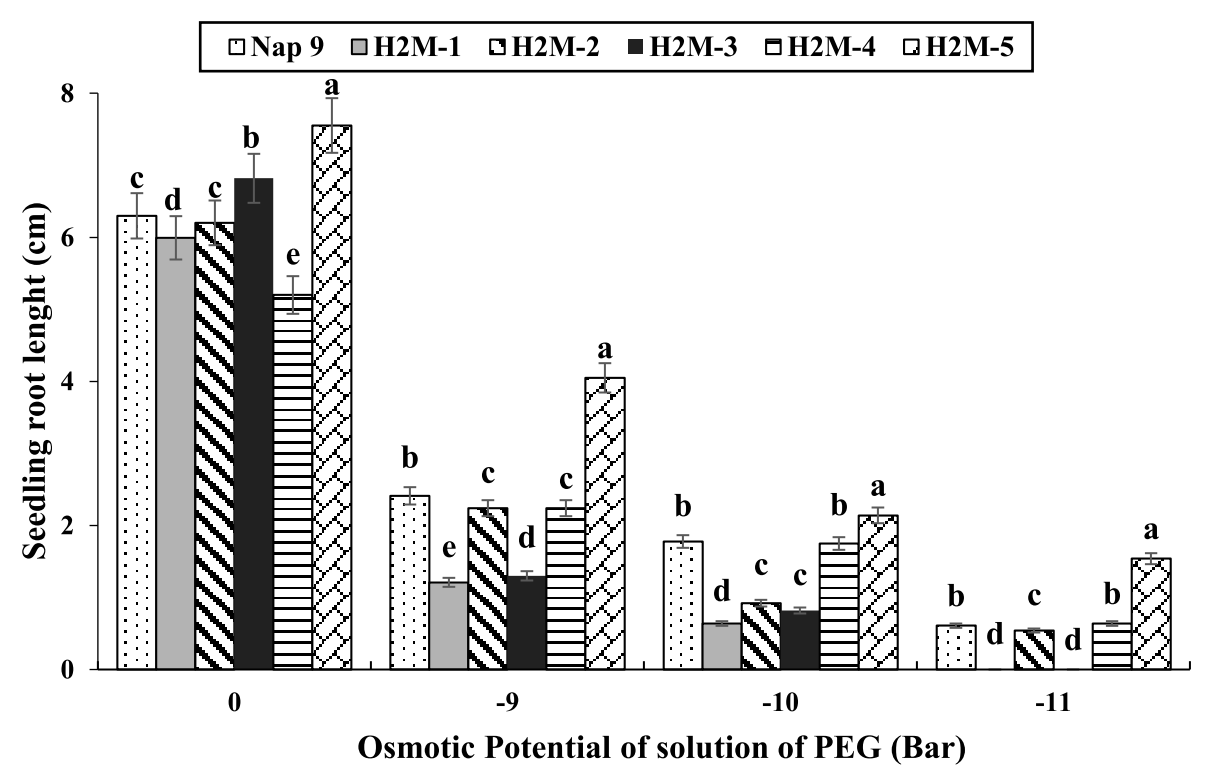

Fig. 5. Effect of PEG induced drought stress on seedling root length of six rapeseed genotypes. (Values with different alphabetical superscripts are significantly different $(p=0.05)$ according to DMRT).

findings of previous studies in Brassica napus (Mohammadi and Amiri, 2010; Channaoui et al., 2017) and in B. juncea (Toosi et al., 2014). However, genotypes 'Nap9' and 'H2M-5' were less affected than the others, indicating that 'Nap9' and 'H2M-5' were the most tolerant to drought stress during germination. To germinate, all rapeseed genotypes could tolerate until -10 bars, and from -11 bars, none of the genotypes ' $\mathrm{H} 2 \mathrm{M}-1$ ' and ' $\mathrm{H} 2 \mathrm{M}-3$ ' could germinate, while 'Nap9', 'H2M-2', 'H2M-4' and 'H2M-5' continued to do it. In our previous study on Moroccan rapeseed varieties, it was found that at -9 bars osmotic potential the germination was reduced drastically, and at -11 bars no germination was recorded (Channaoui et al., 2017). These findings indicate that genotypes 'Nap9', 'H2M-2', 'H2M-4' and 'H2M-5' are more tolerant than the Moroccan rapeseed varieties to drought stress during germination stage. In B. juncea Var. Ensabi, Toosi et al. (2014) reported that -10 and -12 bars completely inhibited seed germination. In sunflower (Kaya et al., 2003) and sesame (El Harfi et al., 2016), it was found that none of the seeds could germinate at -12 bars. However, for safflower, having much bigger seeds, Zraibi et al. (2011) reported that germination ceased already from -2.5 bars.

Reduction in seed germination percentage by drought stress may be attributed to lower infusibility of water through seed coat and initial water uptake of seed under stress condition (Turk et al., 2004; Khayatnezhad and Gholamin, 2011; Bahrami et al., 2012). This could be also explained by metabolic disorders such as slower hydrolysis of storage compounds in endosperm or cotyledons and/or slower transportation of hydrolyzed material to developing embryo axis, under such conditions (Ayaz et al., 2000). Similarly, there might be a deficit of seed hydration due to high osmotic potential, causing inhibition of mechanisms leading to the radicle output from the coat and, thus, seed germination delay (Gill et al., 2003).

Regarding early seedling growth, shoot length and root length generally decreased with increasing drought stress.
There are many reports on various oilseed crops that are in accordance with these findings (Zraibi et al., 2011; Toosi et al., 2014; El Harfi et al., 2016; Channaoui et al., 2017). Actually, drought negative effect on crop productivity often depends on the severity or level of this stress, stress duration and growth stage of the crops (Muscolo et al., 2013). However, previous studies recorded more root length in rapeseed subject to moderate drought stress (Mehanna et al., 2013; Channaoui et al., 2017). More root length under drought was due to the more partitioning of assimilates towards the roots at the expense of shoot growth (Kage et al., 2004). This root elongation under drought stress may help plant to obtain water from deeper soil layers and in this way mitigate drought. However, for root length, the genotypes investigated in the present study reacted differently to the stress levels. Under intermediate stress conditions, the genotypes 'Nap9' and 'H2M-5' were the most interesting, but in severe stress, the genotype 'H2M-5' developed the longest root associated with the highest root elongation rate, indicating its higher tolerance to drought stress during early seedling growth stage, compared to the other genotypes. Besides, the genotypes ' $\mathrm{H} 2 \mathrm{M}-5$ ' and 'H2M-4' were the only ones able to develop shoots at moderate and severe stresses $(-10$ and -11 bars, respectively). Nevertheless, the mutant ' $\mathrm{H} 2 \mathrm{M}-5$ ' had the longest shoot as well as the highest shoot elongation rate.

The ability to develop extensive root system enables genotypes to face soil moisture constraints, mainly during early growth stage. Thus, root length is considered as an important selection criteria for drought resistant cultivars (Turner 1997; Abd Allah et al., 2010). During dry season, topsoil water content is drastically reduced in Mediterranean area. For this reason, plant traits related to water uptake, such as seed germination capacity and root length, are of paramount importance for explaining plant adaptation and persistence in Mediterranean-type ecosystems (Valladares et al., 2004). Germination and seedling establishment are important for determination of final plants density which is highly correlated 

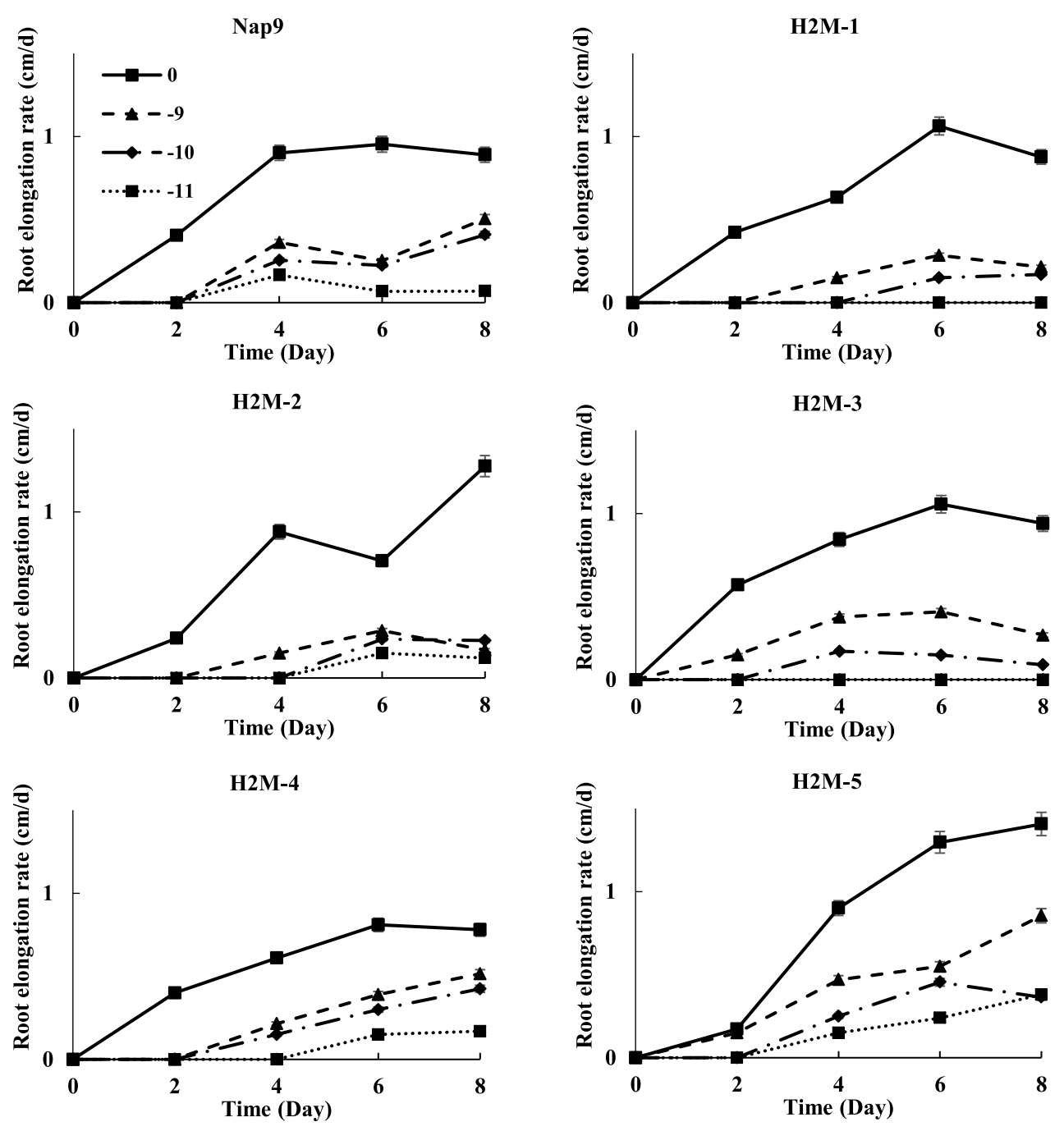

Fig. 6. Effect of PEG induced drought stress (bars) on root elongation rate over time of seeds from six rapeseed genotypes.

with crop yield (Raza et al., 2017). Many reports showed that seeds tolerant to drought stress during germination stage have better growth at seedling stage and also produce strong root system (Waheed, 2014). The plants with more roots at seedling stage subsequently developed stronger root system, produced more green matter and had higher values for most characters determining seed yield (Bocev, 1963).

The studied rapeseed genotypes reacted differently to drought stress occurring during germination and early seedling growth stage. This demonstrates the presence of genetic variability among genotypes toward this abiotic stress and may indicate that tolerance to such a stress can be improved through breeding. Among all genotypes used in this investigation, the genotypes 'H2M-5' and 'Nap9' were interesting since they exhibited, under water stress conditions, highest percentage of germination and required less time to germinate. Particularly, under severe drought conditions, the mutant ' $\mathrm{H} 2 \mathrm{M}-5$ ' is more interesting and promising as it is able to germinate and develop longest shoot and root associated with highest elongation rate.

\section{Conclusion}

Based on the results of this study, there is a genetic variability among the genotypes investigated in their reaction to moisture stress coinciding with seed germination and early seedling growth. Also the related parameters such as germination percentage, shoot length and root length could be used as selection criteria for early and rapid selection of drought tolerant genotypes. The mutant ' $\mathrm{H} 2 \mathrm{M}-5$ ' may be considered as valuable drought tolerant germplasm as it showed a genetic potential to continue to germinate at severe drought stress and to maintain higher seedling growth under moisture stress conditions, compared to the other genotypes. However, before recommending this genotype as suitable germplasm for developing performant and early droughttolerant rapeseed variety, this experiment should be carried out in pots or under field controlled conditions to confirm the findings of this research. Also, this mutant should be further evaluated at adult growth stages to confirm its tolerance to 
drought stress, by monitoring the effects of such stress on morphological, physiological and agronomic attributes. This will open up the possibility to enhance and improve rapeseed establishment and productivity in harsh semiarid environments where water scarcity is more and more frequent in the actual context of climate change.

\section{References}

Abd Allah AA, Badawy Shimaa A, Zayed BA, ElGohary AA. 2010. The role of root system traits in the drought tolerance of rice (Oryza sativa L.). World Acad Sci Eng Technol 68: 1378-1382.

Albuquerque FMC de, Carvalho NM de. 2003. Effect of type of environmental stress on the emergence of sunflower (Helianthus annuus L.), soyabean (Glycine max L.) Merril) and maize (Zea mays L.) seeds with different levels of vigor. Seed Sci Technol 31: 465-467.

Almansouri M, Kinet JM, Lutts S. 2001. Effect of salt and osmotic stresses on germination in durum wheat (Triticum Durum Desf.). Plant Soil 231: 243-254.

Ansari O, Azadi MS, Sharif-Zadeh F, Younesi E. 2013. Effect of hormone priming on germination characteristics and enzyme activity of mountain rye (Secale montanum) seeds under drought stress conditions. J Stress Physiol Biochem 9: 61-71.

Ashraf M, Mehmood S. 1990. Response of four Brassica species to drought stress. Environ Expt Bot 30: 93-100.

Ashraf M, Bokhari H, Cristiti SN. 1992. Variation in osmotic adjustment of lentil (Lens culinaris, Medik) in response to drought. Acta Bot Neerl 41: 51-62.

Ayaz FA, Kadioglu A, Urgut RT. 2000. Water stress effects on the content of low molecular weight carbohydrates and phenolic acids in Cienanthe setosa. Can J Plant Sci 80: 373-378.

Bahrami H, Razmjoo J, Ostadi Jafari A. 2012. Effect of drought stress on germination and seedling growth of sesame cultivars (Sesamum indicum L.). Int J Agri Sci 2(5): 423-428.

Bartels D, Sunkar R. 2005. Drought and salt tolerance in plants. Crit Rev Plant Sci 24: 23-58.

Bocev BV. 1963. Maize selection at an initial phase of development. Kukuruzu 1: 54.

Boyer JS. 1982. Plant productivity and environment. Science 218: 443-448.

Brown SC, Gregory PJ, Cooper PJM, Keatinge JDH. 1989. Root and shoot growth and water use of chickpea (Cicer arietinum) grown in dryland conditions: Effects of sowing date and genotype. J Agri Sci 113: 41-49.

Buchanan BB, Gruissem W, Jones RL. 2000. Biochemistry and molecular biology of plants. Rockville, MD: American Society of Plant Physiologists.

Channaoui S, El Kahkahi R, Charafi J, Mazouz H, El Fechtali M, Nabloussi A. 2017. Germination and seedling growth of a set of rapeseed (Brassica napus) varieties under drought stress conditions. Int $J$ Envir Agric Biotechnol 2(1): 487-494.

Dami I, Haghes GH. 1997. Effect of PEG induced water stress on in vitro hardening of "Valiant" gape. Plant Cell, Tissue Organ C 47: 97-101.

El Harfi M, Hanine H, Rizki H, Latrache H, Nabloussi A. 2016. Effect of drought and salt stresses on germination and early seedling growth of different color-seeds of sesame (Sesamum indicum). Int J Agric Biol 18(06): 1088-1094.

Falusi M, Calamassi R, Tocci A. 1983. Sensitivity of seed germination and seedling root growth to moisture stress in four provenances of Pinus halepensis Mill. Silvae Genetica 32: 4-9.

FAOSTAT. 2018. Available from http://www.fao.org/faostat/en/ \#data/ (last consult: 2018/12/04).

Gill PK, Sharma AD, Singh P, Bhullar SS. 2003. Changes in germination, growth and soluble sugar contents of Sorghum bicolor (L.) Moench seeds under various abiotic stresses. Plant Growth Regul 40: 157-162.

Kage H, Kochler M, Stutzel H. 2004. Root growth and dry matter partitioning of cauliflower under drought stress conditions: Measurement and simulation. Eur J of Agro 20: 379-394.

Kaya MD, Ipek A, Ozturk A. 2003. Effects of different soil salinity levels on germination and seedling growth of safflower (Carthamus tinctorius L.). Turk J Agric 27: 221-227.

Khajeh-Hosseini M, Powell AA, Bingham IJ. 2003. The interaction between salinity stress and seed vigour during germination of soybean seeds. Seed Sci Technol 31: 715-725.

Khayatnezhad M, Gholamin R. 2011. Effects of water and salt stresses on germination and seedling growth in two durum wheat (Triticum durum Desf.) genotypes. Sci Res Essays 6(21): 4597-4603.

Kramer PJ, Boyer JS. 1995. Water relation of plant and soil. San Diego, USA: Academic Press, pp: 1-495.

Larson MM, Shubert GN. 1969. Effect of osmotic water stress on germination and initial development of Ponderosa pine seedlings. Forest Sci 15: 30-36.

Mehanna HM, Hussein MM, Gaballah MS. 2013. Drought alleviation using glutathione in canola plants. Int $J$ of $A d v$ Res 2(9): 679-685.

Michel BE, Kaufmann K, 1973. The osmotic potential of polyethylene glycol 6000. Plant Physiol 51: 914-916.

Mittler R. 2006. Abiotic stress, the field environment and stress combination. Trends Plant Sci 11: 15-19.

Mohammadi GR, Amiri F. 2010. The effect of priming on seed performance of Canola (Brassica napus L.) Under drought stress. Am-Eurasian J Agric Environ Sci 9(2): 202-207.

Muscolo A, Sidari M, Anastasi U, Santonoceto C, Maggio A. 2013. Effect of PEG-induced drought stress on seed germination of four lentil genotypes. J Plant Interaction 9(1): 354-363.

Mwale S, Hamusimbi C, Mwansa K. 2003. Germination, emergence and growth of sunflower (Helianthus annuus L.) in response to osmotic seed priming. Seed Sci Technol 31: 199-206.

Narusaka Y, Nakashima K, Shinwari ZK, et al. 2003. Interaction between two cis-acting elements, ABRE and DRE, in ABA-dependent expression of Arabidopsis rd29A gene in response to dehydration and high salinity stresses. Plant J 34(2): 137-149.

Okcu G, Kaya MD, Atak M. 2005. Effects of salt and drought stresses on germination and seedling growth of pea (Pisum sativum L.). Turk J Agric For 29: 237-242.

Pena RDL, Hughes J. 2007. Improving vegetable productivity in a variable and changing climate. SAT eJournal 4: 1-22.

Raza MA, Shahid AM, Saleem MF, Khan IH, Ahmad S, Ali M, et al. 2017. Effects and management strategies to mitigate drought stress in oilseed rape (Brassica napus L.): A review. ZemdirbysteAgri 104(1): 85-94. 
Shaheen R, Hood-Nowotny RC. 2005. Effect of drought and salinity on carbon isotope discrimination in wheat cultivars. Plant Sci 168: 901-909.

Toosi AF, Bakar BB, Azizi M. 2014. Effect of drought stress by using PEG 6000 on germination and early seedling growth of Brassica juncea Var. Ensabi. Sci P Ser A Agron LVII: 360-363.

Turk MA, Rahmsn A, Tawaha M, Lee KD. 2004. Seed germination and seedling growth of three lentil cultivars under moisture stress. Asian J Plant Sci 3: 394-397.

Turner NC. 1997. Further progress in crop water relations. Adv Agron 58: 293-338.

Valladares F, Vilagrosa A, Penuelas J, et al. 2004. Estres hidrico: Ecofisiologia y escalas de la sequia (Water stress: Ecophysiology and scales of drought). In: Valladeres F, ed. Ecologia del Bosque Mediterraneo en un Mundo Cambiante. Madrid: EGRAF, SA, pp. 163-190.
Waheed A. 2014. Screening and selection of tomato genotypes/ cultivars for drought tolerance using multivariate analysis. Pak J of Bot 46: 1165-1178.

Wanasundara JPD, Mcintosh TC, Perera SP, Withana-Gamage TS, Mitra P. 2016. Canola/rapeseed protein-functionality and nutrition. OCL 23: D407.

Watts DG, El Mourid M. Rainfall Patterns and probabilities in the semi-arid cereal production region of Morocco, USAID project No. 1988, 6080136.

Wu C, Wang Q, Xie B, Wang Z, Cui J, Hu T. 2011. Effects of drought and salt stress on seed germination of three leguminous species. Afr J Biotechnol 10: 17954-17961.

Zraibi L, Nabloussi A, Kajeiou M, El Amrani A, Khalid A, Serghini Caid H. 2011. Comparative germination and seedling growth response to drought and salt stresses in a set of safflower (Carthamus tinctorius) varieties. Seed Technol 33: 39-52.

Cite this article as: Channaoui S, Idrissi ISE, Mazouz H, Nabloussi A. 2019. Reaction of some rapeseed (Brassica napus L.) genotypes to different drought stress levels during germination and seedling growth stages. OCL 26: 23. 